\title{
MITO INDUSTRIAL E IDEOLOGIAS PATRONAIS: o caso do coronel Othon da Fábrica da Macaxeira
}

\author{
Emanuel Moraes*
}

\begin{abstract}
RESUMO: O presente artigo objetiva, de um modo geral, analisar as técnicas de recrutamento de trabalhadores têxteis em uma fábrica com vila operária. Discutiremos as diversas vantagens para a força de trabalho imobilizar sua mão de obra em um emprego assalariado vinculado à habitação de uma casa de vila operária, bem como as relativas desvantagens de tal emprego. Todavia, o foco do artigo está nos aspectos simbólicos da dominação presentes no ato do recrutamento. Estes aspectos atrelados à figura patronal se dão como forma de tornar o emprego assalariado fabril mais atraente que os diversos arranjos de trabalho possíveis no espaço urbano. Assim, relativizando o conceito de liberdade, verificaremos o quanto as questões ideológicas e morais estiveram presentes na forma de dominação de fábrica com vila operária. Para dar conta do objeto, discutiremos os resultados de estudo realizado junto a ex-trabalhadores da Fábrica da Macaxeira.

PALAVRAS-CHAVE: Fábrica; Vila operária; Mito industrial.
\end{abstract}

\section{Industrial myth and patternological ideologies: the case of colonel Othon from the Macaxeira Factory}

\begin{abstract}
This article intends to analyze, in general, the techniques of recruiting textile workers in a company town. We will discuss several advantages for the labor force to immobilize their labor in a salaried employment linked to the housing in a company town, as well as the relative disadvantages of such employment. However, the focus of the article is on the symbolic aspects of domination present in the recruiting act. These aspects linked to the employer figure are given as a way of making factory employment more attractive than the others possible work arrangements in urban space. Thus, relativizing the concept of freedom, we will verify how ideological and moral issues were present in the company town. To accomplish the object, we will discuss the results of a study carried out with the former workers of the Macaxeira Factory. KEYWORDS: Factory; Company Town; Industrial myth.
\end{abstract}

\section{Mito industrial y ideologías patronales: el caso del coronel Othon de la fábrica da Macaxeira}

RESUMEN: Este artículo se dedica, en general, a analizar las técnicas de reclutamiento de trabajadores textiles en una fábrica con una villa obrera. Discutiremos las distintas ventajas para que la fuerza de trabajo inmovilice su mano de obra en un cargo asalariado, vinculado a la vivienda de una casa de villa obrera, así como lo desfavorable de ese empleo. Sin embargo, el enfoque de este artículo está en los aspectos simbólicos de la dominación presentes en el acto del reclutamiento. Estos aspectos junto a la imagen patronal ocurren con el intento de tornar la ocupación asalariada fabril más atractiva que las diversas disposiciones corrientes en el espacio urbano. De esta manera, relativizando el concepto de libertad, percibiremos lo tanto que las cuestiones ideológicas y morales estuvieron presentes en el modo de dominación de fábrica con villa obrera. Para abarcar el objeto, discutiremos los resultados del estudio realizado junto a extrabajadores de la Fábrica da Macaxeira. PALABRAS CLAVES: Fábrica; Villa obrera; Mito industrial.

\footnotetext{
*Mestre em História pela Universidade Federal de Pernambuco. Atualmente é técnico-administrativo em educação pela mesma instituição. Contato: Av. Prof. Moraes Rego, 1235, Cidade Universitária, CEP: 50670901, Recife-PE, Brasil. E-mail: mano-moraes@ hotmail.com. ORCID: http://orcid.org/0000-0002-9078-2661.
} 


\section{O mito do coronel Othon}

A Fábrica da Macaxeira é um caso típico de coincidência de sucesso industrial e personificação da autoridade patronal. São diversos os exemplos de conjunção desse tipo na indústria brasileira: Delmiro Gouveia, Carlos Alberto Menezes, Jorge Street, Francisco Matarazzo, Rodolfo Crespi, Frederico Lundgren.

Fundada ainda no final do século XIX, a Fábrica de Apipucos (denominada pelos populares de Fábrica da Macaxeira) somente veio a obter sucesso econômico e comercial após sua aquisição, em 1925, pelo comerciante de prestígio da Praça do Recife, Othon Bezerra de Mello.

Figura 1: Othon Bezerra de Mello.

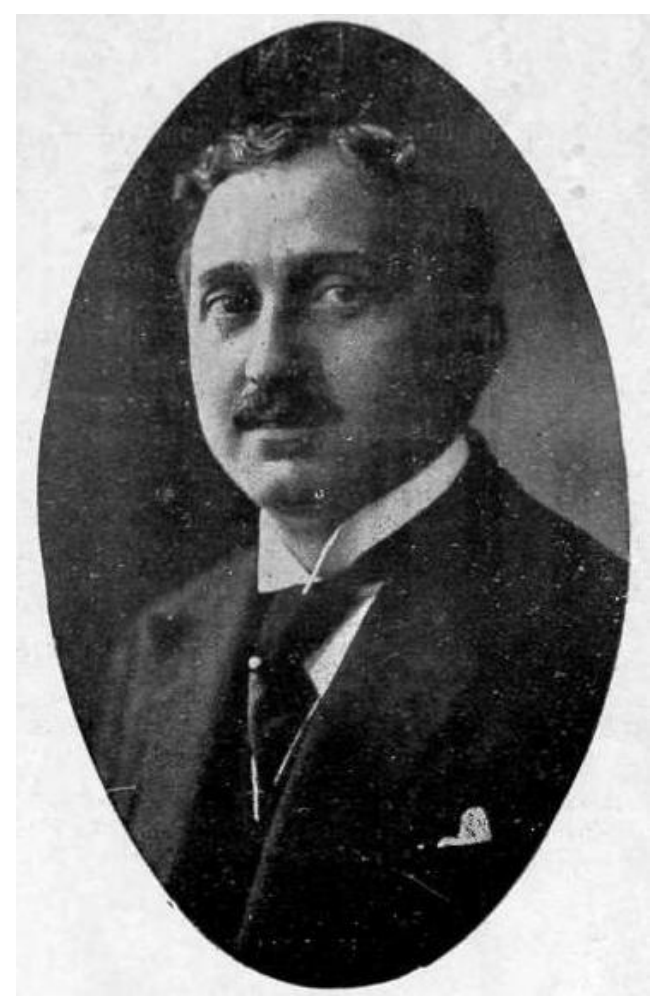

Fonte: Revista da Cidade Anno 1 n 18.

Nascido em 1880, o Coronel Othon, como era largamente conhecido, era filho de um rico comerciante de fazendas de Limoeiro, o também Coronel José Clementino Bezerra de Mello ${ }^{1}$. Em 1905, inaugurou seu primeiro negócio - um comércio a retalhos - em um sobrado da Rua da Cadeia no Bairro do Recife. Em 1911, já havia ampliado o empreendimento com a abertura de uma nova casa comercial na rua do Queimado e outra, funcionando como sede, em um edifício amplo na rua do Imperador (ao lado do Gabinete Português), quando a razão 
social da empresa passou a ser "Othon \& Mendes". Nesse período a já importante firma de importação e exportação de tecidos do Recife chegou a empregar como balconista o jovem adolescente Assis Chateaubriand ${ }^{2}$. Em 1913, Othon Bezerra de Mello casou-se com Maria Amália de Araújo Brito, filha do Senador da República Luís Correia de Brito, gerente da Fábrica de Camaragibe, cuja influência, portanto, se estendia desde o grupo político hegemônico dos Rosistas ao grupo econômico dos industriais católicos ligados às ideias de Carlos Alberto Menezes. Em 1921, Othon Bezerra de Mello foi nomeado $1^{\circ}$ Secretário da Associação Comercial de Pernambuco e em 1926 eleito deputado estadual - inclusive, já havia sido eleito anteriormente conselheiro municipal em 1922. Sua atuação política encerrou-se após a deposição de Estácio Coimbra em 1930.

Figura 2: Othon \& Mendes.

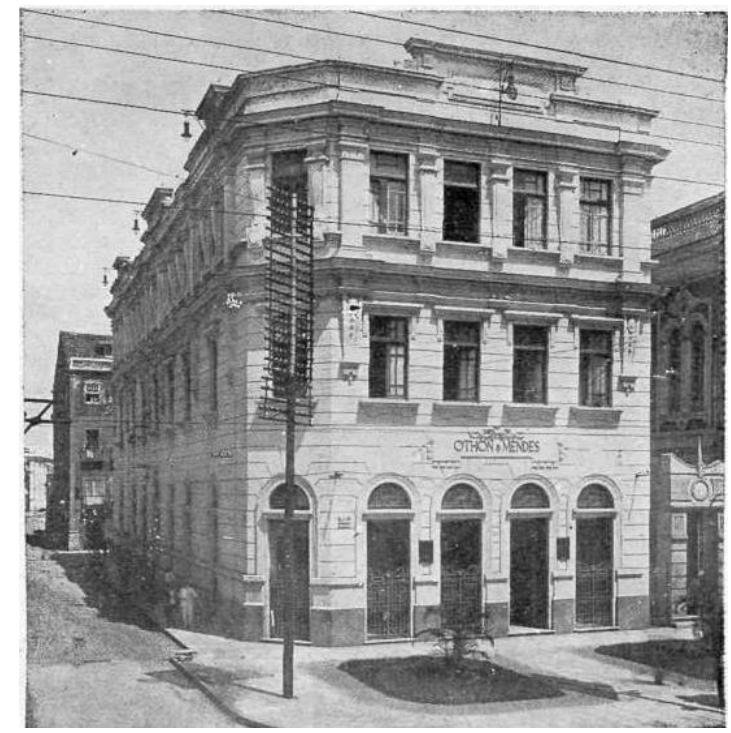

Fonte: Revista da Cidade Anno 1 n 18

Como vimos acima, a compra da fábrica da Macaxeira se deu em 1925. Após isso em 1928, o Coronel Othon inaugurou a Fábrica Bezerra de Mello, localizada na Praça Siqueira Campos, fundindo os dois capitais acionários em uma mesma sociedade anônima, o Cotonifício Othon Bezerra de Mello S.A (COBM). Em 1931 inaugurou a Fábrica Amalita e em 1936 adquiriu a Fábrica de Malha da Várzea ao Conde Pereira Carneiro. Com isso, praticamente estabeleceu um monopólio da produção têxtil da cidade do Recife, tendo talvez como sua principal concorrente a nível local a Fábrica da Torre.

Foi justamente nesse período que mandou erigir a vila operária anexa à Fábrica da Macaxeira. A administração anterior - Braz, Silva e Cia. - mantinha apenas algumas casas 
esparsas, talvez até mocambos, que não configuravam uma política industrial de habitação operária. Por conta disso, em um das primeiras assembleias gerais do COBM junto aos acionistas, Othon Bezerra de Mello demonstrou desde logo ter ciência da necessidade de construir uma vila operária para manter mobilizado e de prontidão para o trabalho um grupo considerável de operários.

(...) Tendo em vista, em primeiro logar, a necessidade de pôr o capital social em equivalencia com o valor actual dos bens sociaes que, como tudo mais, soffreu grande valorisação depois da grande guerra e considerando, em segundo logar, que sendo necessario levar a effeito a ampliação e reforma dos machinismos e edifício existentes e a construcção de casas para operarios, sem as quaes não se pode ter um operariado estável e sufficiente, proponho que seja o capital social elevado para dois mil contos $(\ldots)^{3}$

Obviamente esta conclusão estava respaldada em experiências bem sucedidas anteriormente a nível internacional, nacional e local. Mas sem sombra de dúvidas o modelo Camaragibe - cujo sogro do Coronel era o gerente - teve uma influência primordial não apenas em seu aspecto material mas em seu aspecto simbólico da dominação. Como se sabe o modelo Camaragibe além de contar com os princípios políticos e econômicos do aspecto espacial da vila operária com vistas a obter a "disciplina dos corpos dóceis", contava ainda com uma ideologia católica fortemente baseada na Rerum Novarum, com o intuito de manter “domesticados" os seus operários. Na Fábrica da Macaxeira não foi diferente a partir de sua aquisição pelo Coronel Othon e da construção do primeiro arruado da vila operária. Pois a medida que os operários eram recrutados e alocados gradativamente nas casas, estabeleceu-se sobre a vila operária a dinâmica católica de cultos semanais, catequese das crianças, patrulhamento moral por jovens padres e freiras pertencentes à Juventude Operária Católica.

Fui batizada na escola. Ainda tava em preto, [o Grupo Escolar] Maria Amália, ainda tava em preto [sem acabamento ainda, pois estava em construção]. A freira veio lá em casa, irmã de seu Othon, Dona Alcina [mais conhecida como Madre Lynch]. Era, assim da altura dele. Aí [ela disse]:

- "Zé Campelo, você tem 5 filho pagão, tem vergonha disso não? Por que você juntou 5 menino? (...) Vou batizar tudinho de uma vez só".

Ele disse:

- “eu não posso não, não posso não...”.

- "Não, se preocupe não, que vem tudo, vem meu".

Aí saiu pelas casa todinha, mas não deu roupa a ninguém não só deu a gente. Aí andou pelas casa todinha, arrumou 150 menino pagão - que era pouco operário, era poucas casa, era - aí foi aquela roda na frente da igreja, era igreja [o Grupo Escolar]. Fez aquela roda 150 criança. Mas veio uma caixa quase da largura desse centro, quadrada que aquilo não é quadrada era com tudo: sapato, roupa. A calça do meu irmão com 11 anos dava pra um homem (risos). Dava pra dois dele, é. Meu vestido parecia os vestidos longo de hoje e assim mesmo eu fui batizada. (Edite Campelo, 2012). 
Com efeito, paralelamente à manutenção de uma moral religiosa, foi cultivada uma moral do trabalho associada em grande medida a um relato mítico acerca da trajetória do patrão. Esse é o ponto de partida da nossa análise: a história mítica do patrão descrita no depoimento dos operários.

Estas narrativas nos dão subsídios para entender como era concebida a imagem patronal na mente dos operários. Ou seja, nos dão elementos para entender como o patrão era imaginado pelos operários à época do seu recrutamento junto à empresa, não obstante todos os cargos políticos e o prestígio econômico do Coronel conquistado em anos de atividade industrial e, não obstante, também todas as vantagens materiais oferecidas aos operários como forma de seduzi-los ao emprego fabril. Em uma de nossas entrevistas realizadas junto a exoperários septua e octogenários, este relato mítico-fundador foi reconstruído com riqueza de detalhes.

(...) seu Othon é de Limoeiro. (...) Começou a carregar carga em burro - era burro ele era atacador, era assim atacador, ele carregava na cidade. Então ele trazia é... carga que existia lá no interior dele, o que ele usava, por exemplo, algodão, inhame, batata, o que fosse, o que tivesse ele comprava e trazia nos burros - quatro ou cinco burros que ele tinha. Vinha de pés do Limoeiro por aí afora e passava todo dia nessa pista aí, nessa Estrada do Trem, aqui - o trem passava no Limoeiro e passava aqui então ele vinha nessa estrada direto, né? (...) Chegava aqui se arranchava por isso ou por aquilo, e foi conhecendo. O seu Othon aí com aquele burrado, né, que ele chegava aqui também e começou a comprar fazenda a ele [ao antigo dono da Fábrica que o entrevistado sequer sabe o nome] pra levar pra lá pros arrecife, que é os armazéns: era tudo lá nos arrecifes. Ele começou comprando fazenda, tirando fazenda com ele. Ele ofereceu:

- "Você num quer não, fazenda? Você num negoceia aí?!

- "É, eu num tenho média muito disso de fábrica não - de fazenda não! - mas tudo que vim eu sei vender, porque se eu vendo diversas cargas que eu trago, por que eu não sei vender o algodão - o produto - seu produto?!".

Ele disse [o antigo proprietário]:

- "Então vamos ver nós dois!". - aí pronto, ele pegou deu a ele, vendeu a ele tantos metros: - "Olhe, isso aqui custa tanto, você vende lá a tanto, tem tantos metros de (...) uma peça...”.

Cada peça tinha o quê? cinquenta metros? Sessenta? Trinta? Trinta e cinco? Conforme a peça do produto, né? Tinha produto mais caro, produto mais barato, produto baratinho, como "chita" que o povo dizia antigamente que era "vestido de chita", "Fulano tá com vestido de "chita" - "Chita" era uma fazenda mais baratinha que tinha. Ele dizia:

- "Olhe, leve chita, leve isso, leve... leve o algodão puro, leve tudo, num sei o quê" - aí pronto - "leve que você vai dar bem!".

Aí ele começou, né? Foi conhecendo a fazenda, foi conhecendo aí, foi conhecendo como é que era e foi achando que era bom. E teve tempo de ele [Othon B. de Mello] vim passar dois, três dias com ele [com o antigo dono], conhecendo a Fábrica, né? Ele vinha pra cá, vendia as cargas dele e ficava por aqui. (...) Aí pronto! E foi se fiando dentro da Fábrica com ele, tudinho e tal, quando foi um dia o velho acho que já estava perto de morrer e não tinha quem tomasse conta. Por exemplo, filho que o velho tinha, quem era? - Eu digo velho, pai dele, né? Não! Esse velho que era dono da Fábrica [o próprio entrevistado se corrige] - não tinha gente adequada pra tomar conta, aí ele fez: 
- "Coronel Othon... Coronel! Vamos ver se a gente faz um negócio aqui" - só tinha a frente, onde tem um relógio grande, você pode ver, a frente que era grande, ali só tinha um armazém do lado de cá e dois desse lado: era três armazéns que ele tinha. Só três tecelagens. Só tinha três tecelagens. Ele dizia - "Olhe, eu tenho três tecelagens aqui, já aí e tal" - mas o terreno aí é grande, né? Você sabe que a fábrica aí é muito grande. Ele disse: - "olhe, tenho três tecelagens e tô achando meio mole pra mim e não tem quem deixe".

- "Você tá doido rapaz! Eu vou...".

Ele [o antigo proprietário] disse:

- "Rapaz, todo negócio eu faço com você! Compre a mim essas tecelagens aqui pra tu, rapaz! Você sabe, você já tá dentro da firma, já tá dentro vários tempos aqui comigo, sabe isso aqui o que é, isso só presta agora pra você que você é moço, eu já tô velho, eu já tô dando a idade pra lá e não tem quem tome conta e você é o adequado pra tomar conta disso aqui. Vai ser seu. Assume, rapaz, a gente faz qualquer negócio!".

E assim começou a história e ele assumiu. Comprou ao dono da tecelagem. Ele comprou - o Coronel comprou!

Ele disse:

- "É seu Othon" - "seu Othon não", seu Othon era ele [o próprio entrevistado se corrige novamente] - “é, seu Fulano, eu fico com o coisa. Como é que nós vai fazer?".

Ele disse:

- "Olhe, eu sei que tu num tem dinheiro nem nada, mas arranja aí um pedacinho, tu num negoceia, pô? Tu deve ter algum dinheirinho. Eu preciso de um dinheiro pra cuidar a minha vida, uma coisa e outra e depois tu vai me pagando isso aí como puder. Eu tenho certeza que com tu vai ser bom demais".

Eu sei que, oxe, só deu ele dentro mesmo! (Abdias Silva, ex-motorista, 2013)

Como vimos, tal sucesso obtido junto aos meios políticos oficiais e da burguesia local não era suficiente para conferir legitimidade ao patrão perante os seus subordinados. Era preciso cultivar-se uma narrativa mítica - de uma trajetória ascendente do patrão - constatada na imagem de um caixeiro viajante montado em um jumento que, gradativamente ascendeu social e economicamente, até tornar-se um industrial com a compra à prestação de uma pequena fábrica de tecelagem. Essa história - guardada a verossimilhança com a história oficial do Coronel - tinha claramente a função pedagógica de estabelecer um código de conduta e uma moral do trabalho aos operários através do exemplo patronal. Em última instância, o mito possuía a função de conferir respeitabilidade ao patrão, cujo título de Coronel já contribuía para tal. Sob esse arquétipo, portanto, se fundava o paternalismo de Othon Bezerra de Mello.

\section{A vila operária da Fábrica da Macaxeira}

A vila operária da Fábrica da Macaxeira contava com casas de alvenaria, cujos primeiros arruados foram abertos ainda no final da década de 1920 e receberam as seguintes denominações: ruas do Sol, do Banho, do Reservatório, do Monte, da Barreira, do Cajueiro, 
da Concórdia, $1^{\circ}$ de Maio e Largo da Fábrica. O núcleo da Carrapateira constante de 200 casas, construídas em atacado, dispostas espacialmente nos moldes típicos de uma vila operária - fazendo fronteira com o campo do União FC ao norte e a oeste com o Córrego do Genipapo - se deu em 1934. Já o núcleo do Burity, com 400 casas, foi edificado paulatinamente entre os anos 1941 e 1950, financiadas pelo programa governamental de Agamenon Magalhães, Liga Social Contra o Mocambo. Com a construção da vila operária propriamente dita, os antigos nomes de ruas foram sobrepujados por nomes que remetiam aos parentes do patrão. Na Carrapateira existiam as ruas Maria Amália, Ester, Amalita e Anita. No Burity, as ruas foram batizadas de Madre Lynch, Ana, Regina, Ida ${ }^{5}$.

A Rua Maria Amália - principal arruado da Carrapateira - era destinada aos operários especializados que recebiam salário por produção, operários das seções de fiação e tecelagem, as mais importantes seções produtivas, centralizadoras de toda a organização produtiva da fábrica. Como se tratava de profissões de caráter estratégico para todo o conjunto fabril e determinante para o seu ritmo produtivo, era igualmente estratégica a alocação destes tecelões e fiandeiros em uma rua central da vila operária. As ruas menores da vila operária, tais quais as Ruas Ester e a Amalita, eram constituídas de casas menores, abrigavam trabalhadores marginais à produção, como serventes e trabalhadores das oficinas mecânicas, ou do serviço de manutenção de um modo geral, o que incluía pedreiros, marceneiros, etc, como também abrigava famílias menores em termos numéricos mesmo. Já os motoristas eram prestigiados face ao caráter estratégico que detinham na prestação de serviços à família patronal, podendo barganhar melhores moradias.

No entanto - é por bem que se diga - este acesso ao trabalho e à moradia comportava diversas exceções a estas regras da vigilância e do controle, quase sempre em virtude da precedência das formas tradicionais e subjetivas de obtenção do direito à casa através das relações interpessoais mantidas junto aos gerentes e, mais precisamente, junto ao gerente do externo, homem responsável pela manutenção das casas e de sua alocação pelos trabalhadores, haja vista o quantitativo total das casas ser insuficiente para abrigar a massa dos trabalhadores empregados.

Tabela 1: Operários da Fábrica da Macaxeira ao longo dos anos ${ }^{6}$

\begin{tabular}{|c|c|}
\hline Ano & $\mathbf{N}^{\mathbf{0}}$ de operários \\
\hline 1907 & 200 \\
\hline 1925 & 200 \\
\hline $1928^{*}$ & 800 \\
\hline
\end{tabular}




\begin{tabular}{|l|c|}
\hline 1935 & 1.726 \\
\hline $1941 * *$ & 4.783 \\
\hline $1946 * *$ & 5.000 \\
\hline 1952 & 2.500 \\
\hline
\end{tabular}

* Números relativos à totalidade do COBM (Apipucos e Bezerra de Mello)

** Números relativos à totalidade do COBM (as quatro fábricas)

De todo modo, os mais privilegiados - como não poderia ser diferente - eram os funcionários mais graduados, funcionários de categoria, chefes de seções e gerentes. Estes fugiam a qualquer tipo de critérios interpessoais de alocação, pois a estes empregados eram garantidas casas distintas das casas direcionadas aos operários. Eram casas mais bem arejadas, detentoras de terraço e jardim, localizadas em ruas ou pontos específicos da vila operária e não eram casas geminadas como as dos operários.

Figura 3: Aspecto da vila operária. Em primeiro plano, casas construídas para os mestres (observa-se que as casas não eram conjugadas). Ao fundo nota-se o Mercado e parte da vila operária (casas conjugadas). Lado esquerdo no alto a casa-grande do Coronel.

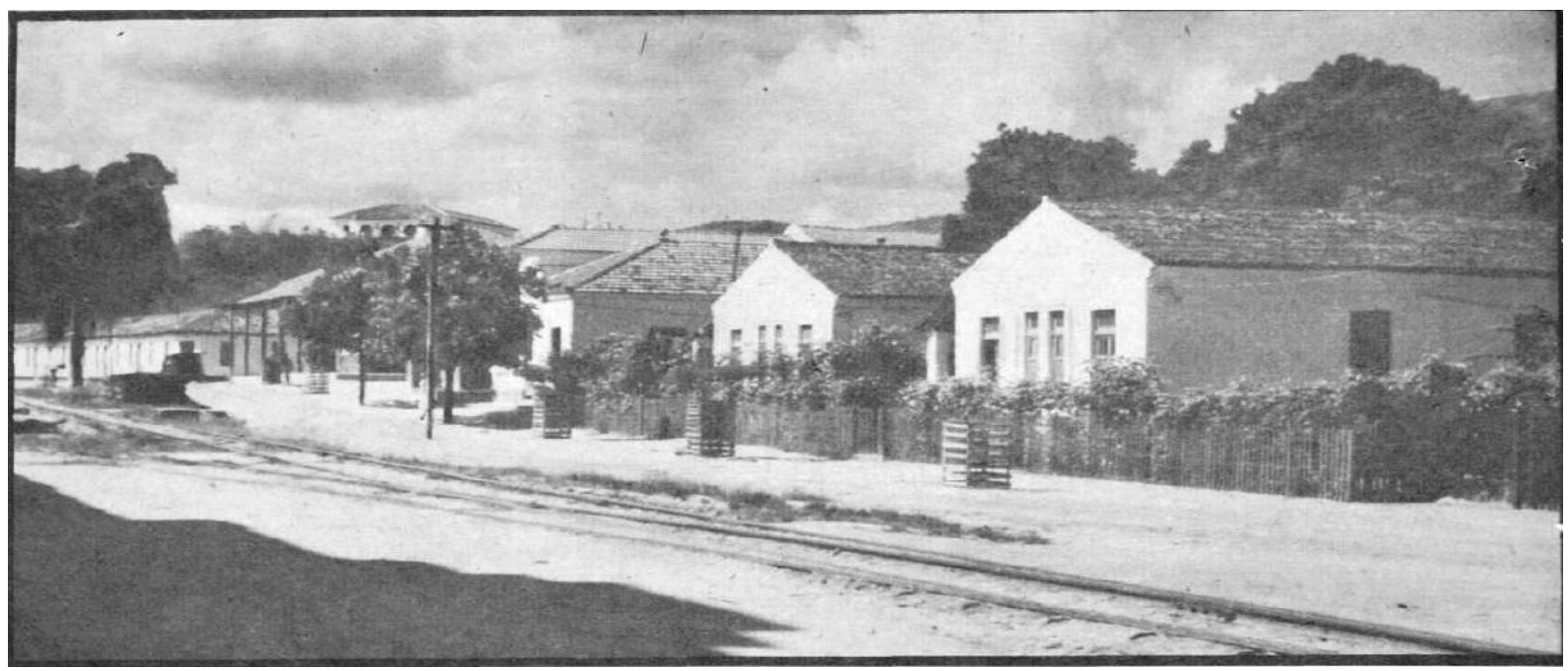

Fonte: O Cruzeiro, 1941.

Além do aluguel a preço módico descontado em folha, havia na vila operária a seguinte estrutura: um estabelecimento de lazer denominado Recreio Operário (edificado em 1928) e os de assistência médica e escolar, Posto Médico Othon Bezerra de Mello (em 1933) e Grupo Escolar Maria Amália (em 1934). No Recreio eram realizados bailes carnavalescos, juninos, festas de final de ano, apresentações da banda operária intitulada de Jazz Othon, exibição de filmes no final de semana gratuitamente, eventos de um modo geral. Havia ainda 
para o abastecimento de gêneros de primeira necessidade o Mercado (construído em 1936) e a Loja de Tecidos (no mesmo ano), cujas compras podiam se dar por meio de vales emitidos nos escritórios da fábrica - mais precisamente pelo gerente do externo -, podendo ainda serem descontadas parceladamente no contracheque.

De qualquer maneira, a administração fabril atuou de forma incisiva no campo discursivo para insinuar aos trabalhadores recrutados e alojados nas casas de propriedade da fábrica uma "moral do trabalho" fundamentada nessa "economia moral" da vila operária, cujo objetivo principal era justificar tal forma de dominação em um mercado de trabalho livre, composto por trabalhadores "duplamente livres", em termos de liberdade de ir e vir e de escolha quanto ao contrato de trabalho, ao passo que despossuídos dos meios de produção ${ }^{7}$. Nos relatórios apresentados aos acionistas a "economia moral" aparecia com o nome de "serviço de assistência".

\section{(...) SERVIÇO DE ASSISTÊNCIA}

A associação Beneficente dos Operarios em ambas as fabricas continua a prestarlhes os serviços de assistencia medica e auxílios. A de Apipucos offerece instrucção aos filhos de seus operarios e para recreio dos seus associados inaugurou um cinema que proporciona aos operarios secções cinematographicas uma vez por semana.

Em ambas as fabricas instalou-se o serviço de assistencia dentaria, já tendo sido adquirido todo material necessario.

$\mathrm{Na}$ conceituada Companhia Seguradora Industria, continuam segurados contra os accidentes de trabalho, todos os seus operarios. ${ }^{8}$

E a tudo isso se somou o estímulo a um "mito de origem"9 legitimador destes critérios subjetivos de admissão que marcaram o recrutamento da força de trabalho ao longo das décadas de 1920 e 1940, a partir destes processos centrados na imagem personalista do patrão, ou seja, do Coronel Othon enquanto uma figura paternalista responsável pelo provimento do emprego e da moradia e das demais formas de concessões feitas aos operários $^{10}$.

(...) na época de finado Othon, ali era um pai. Tia Lia chamava ele de papai Othon, porque vestido mesmo, de noiva, que eu trabalhava, quem me deu foi ele. Ele dava do véu ao sapato, ele dava. (...) Qualquer funcionário, podia ser pobre, podia ser tecelã, podia ser o escriturário. ${ }^{11}$

Essa moral do trabalho "paterna", atenuante da dureza das jornadas de trabalho no interior da planta fabril e recompensadora a nível de suprimento doméstico das famílias operárias, visava também evitar o surgimento dos conflitos de classe. Todavia, em detrimento ao que justamente a vila operária almejava obstruir, houve já no início da década de 1930 perdurante pelas décadas seguintes até a década de 1960 - os primeiros conflitos de classe no 
âmbito da vila operária através de comícios e distribuição de panfletos por operários vinculados ao comunismo. Estes atos foram noticiados em um hebdomadário intitulado Norte Proletário.

\begin{abstract}
Na Fabrica da macaxeira á tarde de 11 do corrente levaram a efeito animado comício os camaradas delegados da União Geral dos Trabalhadores de Pernambuco. Persuadindo á generosa massa trabalhadora a syndicalisar-se de accordo com o programma da (U. G. T. P.) União Geral dos Trabalhadores de Pernambuco ora legalisada legitimamente pelos syndicatos independentes, falaram os tres últimos companheiros. Ouviram-nos com applauso todo o pessoal da fabrica devoluto naquella hora ficando propenso a nos adherir. Antes e após o comício distribuimos com desusada acceitação exemplares desta folha. Alguns estragaram-se á ancia de sua obtenção pelos camaradas. Voltamos convencidos de que estes, mesmo dentro da fabrica, saberão estender nossa propaganda de syndicalisação e que, esperam de muito bom grado ouvir-nos outra vez. Gratíssimos camaradas trabalhadores e trabalhadoras, pela attenção que nos dispensases. ${ }^{12}$
\end{abstract}

Independentemente dos conflitos de classe, o programa patronal de manutenção de uma "economia moral" dentro da vila operária persistiu durante toda década de 1930, 1940 e 1950 décadas de pleno crescimento econômico da empresa, de expansão da produção, das vendas, da contratação de mão de obra e de edificação de sua vila operária. A década de 1930, apesar da alegada crise de superprodução e da proibição da importação de maquinários para a indústria têxtil, foi para o Cotonifício Othon Bezerra de Mello uma década de modernização de seus maquinários, devido a posição politicamente ambígua de Othon Bezerra de Mello no jogo econômico travado com os irmãos Lundgren a nível local e com os industriais do sul do país (sediados nos sindicatos patronais do Rio e de São Paulo) a nível nacional ${ }^{13}$. A década de 1940 foi favorecida pela posição ocupada pelo Brasil durante o conflito mundial, cuja demanda de guerra caiu de paraquedas sobre o colo dos proprietários do parque industrial brasileiro. Com isso, os lucros de guerra foram astronômicos e poderiam ter sido ainda maiores não fosse a guerra fratricida da década de 1930, travada entre os grandes e pequenos industriais, e que estava por detrás do discurso da crise de superprodução têxtil.

Nesse contexto é que houve a contratação maciça de trabalhadores. Othon Bezerra de Mello comprou a fábrica em 1925 com 200 operários empregados. Em 1928, já eram 800. Óbvio que os números relativos a este ano se referem às duas fábricas pertencentes ao COBM naquele momento. Se considerarmos que o quantitativo referente à Fábrica da Macaxeira fosse a metade, teríamos pelo menos a duplicação do número de funcionários. Todavia, como sabemos que esta fábrica era central no processo produtivo, talvez 500 ou 550 operários fossem vinculados à Fábrica da Macaxeira e somente o restante à Fábrica Bezerra de Mello na Praça Siqueira Campos. Assim, o recrutamento massivo de trabalhadores naquela ocasião 
chegou a motivar conflito intraburguês por conta da concorrência pela mão de obra especializada. Othon Bezerra de Mello chegou a acusar Frederico Lundgren de plagiar suas marcas, de sabotar sua seção de estamparia da Fábrica de Apipucos e de incendiar criminosamente o armazém da Fábrica Bezerra de Mello ${ }^{14}$.

Durante a II Guerra Mundial, a fábrica da Macaxeira chegou a empregar mais de 3000 trabalhadores, entre operários propriamente ditos, envolvidos com o processo produtivo do tecido, e o pessoal destacado para os serviços externos: mecânicos, pedreiros, motoristas, etc. Por isso o crescimento paulatino da vila operária, sua constante insuficiência e os critérios interpessoais - que funcionavam como meio de seleção natural no processo de recrutamento e de alojamento das famílias nas casas da vila operária - operaram com todo vigor.

Talvez não fosse preciso dizer em face da obviedade da afirmação mas, - não custa nada reiterar - a fábrica da Macaxeira era a principal fonte de emprego da área suburbana da zona norte da cidade do Recife. A freguesia do Poço, na área de abrangência do tradicional bairro de Casa Amarela já na década de 1930 era densamente povoada em torno da feira livre e em suas cadeias de morro: Alto Santa Isabel, Alto do Mandú, Morro da Conceição, Vasco da Gama, Nova Descoberta, Córrego do Genipapo, apenas para citar exemplos. Além de resquícios quilombolas, esta região foi alvo da invasão migratória dos "sertanejos" do interior pernambucano em virtude das secas de 1919-1921 e 1934-1936. A crise populacional decorrente dela e da haussmanização da área portuária do Bairro do Recife em partes motivaram a criação da Liga Social Contra o Mocambo pelo governador Agamenon Magalhães ${ }^{15}$.

Com efeito, a demanda pelo emprego era bastante alta. Por sua vez, os sujeitos demandantes do emprego eram dotados de escolha. Isto porque optar por estabelecer-se na vila operária implicava uma série de consequências, boa parte das quais, em termos de controle e disciplina, demonstramos acima. Havia também outras possibilidades de ocupação, cujos arranjos de trabalho em toda a cidade do Recife eram vários, perpassando pelo mercado de trabalho das fábricas de tecido - somente na região metropolitana existiam nove fábricas -, das demais indústrias e empregos formais no funcionalismo público, na repartição de obras e limpeza urbana, no comércio varejista. Em termos de ocupações não formais, os sujeitos podiam se reproduzir trabalhando como vendedor ambulante no centro da cidade, como pescador nos rios Capibaribe e Beberibe ou no Açude de Apipucos (havia aqui também as lavadeiras de ganho) - no caso mais concreto do nosso objeto de estudo -, como feirante e em 
suas posições anexas tal como a de carregador de frete, ou ainda como artista no exercício de um ofício específico tal como o de ferreiro, marceneiro, alfaiate, etc. Não objetivamos aqui dar conta de todas as ocupações que rivalizavam com o mercado de trabalho têxtil, mas apenas demonstrar a amplitude dos arranjos de emprego e ocupações existentes na cidade que se colocavam ao sujeito trabalhador na hora de escolher como dispor de sua força de trabalho.

E é justamente neste ponto que entram os aspectos subjetivos da sedução do trabalhador ao emprego assalariado fabril. Pois, como vimos, a oferta de uma casa em vila operária - ainda que nem sempre garantida - com suas "regalias" adjacentes não eram suficientes para atrair os trabalhadores. Ou, visto de outro ponto de vista, não eram suficientes o bastante para justificar a sujeição do trabalhador a uma ampla dominação abarcando não apenas a esfera do trabalho mas junto a esta a esfera doméstica do sujeito. Além do mais, todas as fábricas concorrentes pela mão de obra qualificada têxtil e mesmo pela mão de obra subqualificada eram detentoras de vilas operárias como quesito de atração da força de trabalho. Para tanto, o paternalismo e a configuração mitológica desses patrões acirravam a disputa pela mão de obra e, inversamente, justificava a sujeição por parte destes pela interiorização e reapropriação do discurso grandiloquente patronal.

\section{Emprego e moradia}

Os dados estatísticos do Instituto Brasileiro de Geografia e Estatística/IBGE, acerca do país e mais especificamente do estado de Pernambuco, embora não se aprofunde nos números relativos à capital Recife, parecem ser esclarecedores, por amostragem, do que intentamos constatar. Apenas para termos uma ideia, o recenseamento de 1920 da população do Brasil e de suas unidades políticas, segundo as categorias de profissionais, estimava que de uma população de 2.154.835 (duas milhões, cento e cinquenta e quatro mil, oitocentas e trinta e cinco pessoas) no estado de Pernambuco apenas 70 mil estavam empregadas na indústria. Outras cerca de 580 mil pessoas estavam empregadas nos ramos de exploração do solo, extração de minerais, transportes, comércio, administração pública, administração particular ou exercendo atividade de profissional liberal, de acordo com as categorizações do IBGE. As demais 1,5 milhão de pessoas por não se incluírem em qualquer uma dessas categorias eram categorizadas como exercendo "atividades diversas", seja por não possuir profissão ou então por não a declarar. A informalidade do emprego perdurou mesmo após a instituição da carteira profissional por meio do Decreto $\mathrm{n}^{\circ} 21.175$, de 21 de março de 1932, pois o mesmo 
Anuário de Estatísticas do IBGE publicado em 1936 mostrava que entre 1933-34 em Pernambuco, apenas 30 mil carteiras profissionais foram requisitadas pelos empregadores para seus empregados, e dessas somente 22 mil foram expedidas, conforme a capacidade do MTIC atender a demanda ${ }^{16}$.

Estes dados relativos ao estado de Pernambuco entre as décadas de 1920 e 1930 mostram o quanto a informalidade do emprego era considerável no estado, e o quanto mesmo entre os trabalhadores devidamente empregados nas indústrias, havia certa precariedade dos laços empregatícios, ao constatarmos o descompasso do número de pessoas empregadas no ramo e o número total de carteiras de trabalho expedidas nos anos iniciais após a sua instituição. Como também mostra certa situação conflitiva, ante a resistência dos empregadores em atender a legislação e a reativa exigência dos empregados pela efetivação de seus direitos ${ }^{17}$. Ademais, embora esta discrepância significativa nos números possa indicar certa persistência da clandestinidade nos vínculos de emprego mesmo que industrial e mesmo após a imediata instituição da carteira profissional, ainda assim, empregar-se em uma indústria parecia ser vantajoso, sobretudo quando se referia a uma indústria têxtil que oferecia além do emprego, a moradia a preço módico, a assistência médica e escolar e o lazer de um modo geral para o operariado e sua família. Tais facilidades, asseguradas enquanto direitos tácitos dos trabalhadores, constituíam-se como um forte atrativo que se somava à obtenção de um emprego considerado seguro se comparado às demais formas de ocupação e de ofertas de emprego da cidade do Recife.

Sendo assim, a Fábrica da Macaxeira, a partir da administração do Coronel Othon, passou a configurar-se como a principal fonte de emprego formal da localidade em que estava inserida, e assim ao atrair a demanda por emprego dessa área extremamente populosa precisou estabelecer critérios responsáveis pela delimitação do abundante mercado de trabalho que a circundava. Isto porque, diante da ampla informalidade do trabalho característico da área urbana em que estava inserida, a formalidade do emprego passou a ser um grande atrativo para os trabalhadores urbanos desempregados, independente das desvantagens manifestamente existentes no emprego do tipo formal, sobretudo para trabalhadores acostumados a padrões distintos de trabalho e emprego, relativamente à rigidez do vínculo empregatício caracterizado pela estreiteza da jornada de trabalho, devidamente acionada pelos apitos da Fábrica que sinalizavam o início e o término da cada turno de trabalho; da exploração econômica dentro do ambiente fabril e da dominação social fora dele (exercido duplamente, por intermédio da propriedade da casa dos operários pelo mesmo 
patrão que oferecia o emprego $)^{18}$. Por outro lado, o emprego em um fábrica possibilitava ao trabalhador certa segurança no emprego - o que diferia bastante dos vínculos empregatícios em pequenos estabelecimentos comerciais ou no meio rural -, e a garantia de direitos trabalhistas, como por exemplo, a partir de 1943, com a CLT, a obtenção da estabilidade decenal $^{19}$. Com efeito, a sensação de proteção sob um patrão forte - detentor de uma história mítica, ostentando o título de Coronel - e, consequentemente, de uma firma forte, dava certa segurança aos operários contra o desemprego e o desalojamento, em virtude das incertezas do mercado de trabalho, dos imponderáveis das ocupações autônomas e do alto custo da moradia e da reprodução familiar no espaço urbano.

Deste modo, e em vista da abundante força de trabalho de que precisava para fazer frente aos objetivos de reprodução do capital, a direção da fábrica estabeleceu três critérios de admissão com vistas a delimitar o considerável mercado de trabalho próprio à localidade extremamente populosa em que estava inserida a planta fabril ${ }^{20}$. Eram eles: 1) as formas personalizadas de recrutamento ("amizade, parentesco e vizinhança") ${ }^{21}$; 2) o grau de especialização técnica do trabalhador-operário, mesmo que desenvolvido em outras indústrias que não a têxtil; e finalmente, 3) o próprio mercado de trabalho têxtil, que configurava certa disputa dos industriais de tecido por suas forças de trabalho devidamente "obreirizadas"22.

Com estes critérios a administração fabril conseguia restringir bastante o mercado de trabalho abundante que lhe fazia pressão constantemente por emprego, ao passo que a despeito dos critérios técnicos e essenciais para o bom funcionamento da fábrica elencados nos itens 2 e 3, mantinha ainda, por outro lado, critérios subjetivos e interpessoais característicos do modelo paternalista de exploração econômica, centrado na personalidade do Coronel Othon, como o principal responsável pela concessão do emprego. Pois se por um lado a abundância do mercado de trabalho que se lhe abria devido a área extremamente populosa onde estava instalada a indústria configurava uma posição relativamente cômoda no mercado de trabalho, por outro lado, a Fábrica, mesmo sendo uma importante fonte de emprego local - haja vista o aumento considerável de absorção de força de trabalho pela Fábrica nos anos que se sucederam à compra da mesma por Othon Bezerra de Mello -, ainda assim necessitava da contratação estratégica de operários especializados.

Não obstante, estes números relativos à absorção cada vez mais intensiva de mão de obra por parte da Fábrica da Macaxeira são bastante significativos da constituição da mesma enquanto principal fonte de emprego da área suburbana na qual estava inserida. Contudo, se 
faz importante perceber o quanto os critérios utilizados para a contratação de pessoal, sobretudo aquele que considerava as relações interpessoais do gerente geral da Fábrica, Severino Barros e dos demais gerentes das seções diversas, foi modelador da força de trabalho recrutada para a Fábrica neste momento do estabelecimento dessa mão de obra original, duplamente dependente da administração fabril por meio, de um lado, do vínculo empregatício e, do outro, do vínculo moral do usufruto do aluguel de uma casa na vila operária atrelada à condição do emprego, a preço abaixo do de mercado. Este vínculo “moral”, na verdade, derivava primordialmente do vínculo empregatício na Fábrica, e era constituinte do que chamamos de "economia moral" da vila operária. Porque esta "economia moral" fundamentava-se justamente na dupla submissão do trabalhador ao mesmo proprietário da indústria e da moradia, o qual legitimava esse forte poder de dominação inerente ao sistema de fábrica com vila operária através das diversas concessões extramonetárias conferidas aos trabalhadores como se fossem direitos tacitamente acordados, por intermédio de instituições construídas no perímetro da vila operária, as quais lhes eram subsidiárias e complementares aos baixos salários pagos aos operários ${ }^{23}$. Tal fato demonstrava a extrema dependência econômica dos operários com relação à "economia moral" mantida pelo patrão. Por isso mesmo, esse critério de empregar pessoas detentoras de laços de parentesco, amizade e vizinhança, constituía-se como o principal método de recrutamento da força de trabalho, porque tal critério personalista, ou mesmo paternalista, de gestão de pessoal comportava o valor moral da "lealdade" peculiar nesse modelo de manutenção das relações de trabalho.

Era bom demais essa fábrica. E só empregava filho de operário. Estranho não entrava. Só família. Só família. (Francisco Lima, ex-torneiro mecânico, 2013)

Com efeito, supomos que a organização originária da força de trabalho empregada a partir da administração de Othon Bezerra de Mello fosse constitutiva concomitantemente das três formas elencadas acima (1- critérios personalizados de amizade, parentesco e vizinhança; 2- operários fabris lato sensu; e 3- operários fabris têxteis), somadas à permanência de operários empregados desde a antiga "Braz, Silva e Cia" ${ }^{24}$. De modo que relativamente aos critérios de contratação de operários fabris lato sensu e operários fabris do próprio mercado de trabalho das fábricas têxteis, estes eram contratados para suprir posições estratégicas da produção e da hierarquia fabril (fiação, tecelagem, tinturaria, estamparia, fiscais, vigias, contramestres), ou seja, operários profundamente especializados e de confiança da administração. E por outro lado, a contratação do grosso dos empregados, a maioria deles 
ingressantes como ajudantes e/ou em posições acessórias ou nas seções de preparação do fio, dependentes de um processo intensivo de "obreirização" e de aprendizagem dos ensinamentos tácitos que compreendia a "economia moral" da vila operária, estes eram contratados prioritariamente pelos critérios personalizados.

Eu entrei através de um padrinho meu que era encarregado, meu padrinho padrinho mesmo de batismo - ele trabalhava e era muito querido na fábrica. (...) Daí um dia eu tava precisando de trabalho, pai tava meio doente, aí meu pai disse assim: - "vou chamar seu padrinho, pra ele lhe botar pra trabalhar na fábrica". Aí chamou ele, aí ele disse assim:

- "Eu vou, eu vou falar com seu Luís Bernardino" - que era o gerente, na época era gerente da embalagem, quando eu trabalhava, na seção da embalagem, e tinha outro que era gerente da Fábrica toda e eu me esqueço o nome dele, depois eu me lembro; e então aí, ele disse assim - "Vou falar com Luís Bernardino" - que é o gerente da embalagem - "pra botar ela lá na embalagem, que tem menina de menor e é um trabalho limpo" - lá era muito limpo, era um lugar bonito, muito silencioso (...).

Eu morava em Sítio Grande. Aí ele disse assim:

- "Mande ela assinar o nome dela, endereço, pra ver se ela sabe assinar". Eu treinei e fiz tudinho direitinho, e ele levou minha letra pra Luís Bernardino que era o gerente. Aí ele disse:

- "Traga ela pra eu ver, a menina". Aí ele me levou e eu fiquei trabalhando. Só com isso que eu sabia. (Lourdes, ex-operária da seção de embalagens, 2012).

Como se pode ver, os habitantes das redondezas - como era o caso dessa ex-operária da seção de embalagem - necessitavam de certo aval de um operário já empregado que facilitasse o acesso ao emprego do pleiteante. O que obviamente era mais eficaz quando o pleiteante ao emprego era residente em áreas próximas da Fábrica, a exemplo de Sítio Grande $^{25}$. Com efeito, o único teste objetivo exigido pelo pessoal dos escritórios a fim de determinar o direito a obtenção da vaga de trabalho era a comprovação do domínio da técnica da escrita e da leitura (alfabetização) através da assinatura do nome do candidato, como se isso fosse o suficiente. Pois na verdade, tratava-se de um "discurso público", ou seja, de uma forma de legitimação pública de critérios de recrutamento, encontrado pela administração fabril para justificar objetivamente a contratação de pessoal, a qual quase sempre ocorria por via de favores pessoais.

Ademais, além da garantia do emprego por meio das relações interpessoais travadas com pessoas que já trabalhavam na Fábrica, seja de parentesco, amizade ou vizinhança, critério subjetivo este que se mostrava relativamente mais eficaz quando se tratava de pessoas com maior poder de influência nos escritórios, mais especificamente no "departamento de pessoal", sobretudo os chefes, encarregados das seções ou ocupantes de cargos nas chefias imediatas (contramestres) e de confiança do patronato (vigia e motorista). Este mesmo critério - eficaz, excepcionalmente no caso da obtenção de emprego, também para operários 
do baixo escalão detentores de prestígio pessoal dentro da Fábrica - era mormente utilizado para a colocação no emprego em uma seção de trabalho mais favorável seja em termos de insalubridade, como era o caso da colocação de mulheres jovens e bem referenciadas dentro da fábrica por seus laços de amizade e parentesco, em seções consideradas limpas (física e moralmente ${ }^{26}$ ) a exemplo da seção de embalagens dos fardos de tecidos; seja ainda em termos econômicos, quando no caso de alocações nas seções onde se ganhava por produção (fiação e tecelagem, de um modo geral).

A minha irmã me botou no liçador. Seu Artur Ferreira era mestre da fiação, da bobina e da engomadeira. Eu só vivia lá no liçador brincando com as meninas. Aí o liçador só tinha três máquinas de fiação, de... de liçar, a engomadeira só tinha uma máquina, a fiação só tinha uma carreira de máquina depois foi que aumentou, aí fui trabalhar no liçador. (...) Mas todo o dinheiro era por semana. Toda semana quando eu recebia dinheiro, chegava em casa com o envelope do jeito que eu recebia dava a minha irmã. Ai teve um dia: "eu vou tirar você de lá, vou botar na tecelagem que lá é produção e você vai ganhar mais dinheiro". Na tecelagem ganhava por produção, era 9 real, 10 real, nunca recebi 15 . E na tecelagem era produção, as meninas tiravam de 18 pra cima. Aí ela falou com seu Artur Ferreira, que era o mestre, pra me botar na tecelagem. (...) Depois fui pra tecelagem ser fiscal. A tecelagem todinha. Era o dia todinho você chega cansada. Que a tecelagem tinha pouca máquina, só era metade da Fábrica. Mas tinha muita máquina, tinha muita máquina tanto de tecelagem como da engomadeira que era embaixo e a entrada da espula que era já no fim. Eu andava o dia todinho, ganhava bem, ganhava 35 mil reis, a minha irmã ficava doida, que a minha irmã gostava muito de dinheiro viu (risos). (Edite, ex-tecelã, 2012)

Ou seja, a questão normalmente não se encerrava no simples fato de obter uma vaga de emprego dentro da Fábrica, através dos vínculos pessoais existentes, mas exigia, muitas vezes, a reutilização deste mesmo expediente para alocação em postos de trabalhos considerados mais vantajosos de acordo com a subjetividade de cada um. Isto porque, como afirmamos acima, a colocação em determinadas seções, de acordo com a invocação do conhecimento dependia do objetivo de quem pleiteava a vaga, seja o critério higiênico (e até mesmo moral) ou econômico. Ou seja, muitas mulheres eram lotadas nas seções consideradas higiênicas, a pedido dos pais ou maridos, enquanto que outros trabalhadores, desta vez independente do sexo, optavam prioritariamente pelas seções produtivas, nas quais o salário era pago por produção. Tudo isso significava uma luta intensa de bastidores entre os operários que se debatiam para na prática saber quem tinha mais poder de influência junto à administração fabril para ter seus pleitos atendidos, como também revelava a existência de uma intensa movimentação de pessoal dentro da própria Fábrica, ou ainda pelas demais unidades pertencentes ao COBM, como forma de "promoção" ou inversamente de "despromoção". 
Como não obtivemos acesso à documentação do "departamento de pessoal” da fábrica para atestar a proveniência da mão de obra, os laços de parentesco e a magnitude da movimentação de pessoal por entre as seções e fábricas pertencentes ao COBM, recorremos à publicação das notícias de jornais relativas à "Festa da Eficiência" - nas quais além de se premiarem os operários "eficientes", nos termos do modelo produtivista implantado ao final da década de 1940, como resultado da intensificação da produção nos anos da II Guerra, eram premiados nestes "cerimoniais institucional-paternalista" os operários que completavam 25 anos de emprego no COBM. Com efeito, na publicação que dava conta da "Festa da Eficiência" e da distribuição de prêmios para os operários produtivos, saia um quadro com um pequeno histórico dos operários que naquele ano completariam o "jubileu de prata". Estes quadros, publicados para os anos de 1954 e 1955, continham dados que nos parece terem sido formulados a partir dos dados funcionais dos operários registrados nos escritórios do Cotonifício Othon Bezerra de Mello. De modo que nos serviram para atestar a possibilidade de ascensão dentro da empresa dos empregados que detinham relações interpessoais suficientemente fortes para garantir o usufruto de benefícios conseguidos com base justamente nestes critérios e a despeito de critérios objetivos de competência facilmente comprovada na prática cotidiana do trabalho dentro da Fábrica.

Contudo, convém lembrar que estes dados aqui apresentados, pelo fato de terem sido selecionados a partir da perspectiva do capital para apresentação ao público por meio de uma notícia paga veiculada na grande imprensa com vistas à manutenção de uma boa aparência quanto ao exercício da dominação, escondia, por que não, a utilização inversa deste mesmo critério para punir os trabalhadores que dele não se fizesse valer. Ou seja, isto significa dizer que a administração fabril jamais tornariam públicas decisões administrativas relativas às suspensões injustas impostas aos trabalhadores, seja em termos da exploração econômica fabril, seja em termos de retaliação à objeção política a essas práticas, ou ainda, as mudanças de categoria dos trabalhadores ou até mesmo de seção de trabalho e de fábrica (transferência do operário da Macaxeira para a fábrica da Várzea ou para uma das duas da Praça Sérgio Loreto e vice-versa), com vistas a punir e/ou prejudicar (“despromover”) o trabalhador que fosse julgado inconveniente para a empresa por lhe ser politicamente contrário e/ou que não tivesse boas relações com a hierarquia fabril.

MANOEL ANTONIO DE SOUZA: - Começou a trabalhar na Emprêsa a partir de 18 de janeiro de 1927, como vigia da antiga Fábrica de Apipucos, hoje Coronel Othon. Trabalhou algum tempo como vigia da Fábrica Bezerra de Mello e atualmente se encontra trabalhando como vigia da Fábrica Coronel Othon. Trata-se 
de um empregado fiel e cumpridor dos seus deveres, merecendo dos diretores da Emprêsa inteira confiança. (...)

MANUEL VICENTE FERREIRA: - Admitido em 18 de janeiro de 1927 na secção do acabamento da Fábrica Coronel Othon, foi posteriormente transferido para a secção de embalagem, onde continua trabalhando, sem a menor interrupção no seu tempo de serviço. Nunca foi suspenso e é um empregado ordeiro, trabalhador e cumpridor das suas obrigações.

ARTHUR FERREIRA DE LIMA: - Admitido em 5 de dezembro de 1927 como engomador de fios, tendo exercido êsse mister durante vários anos após o que foi promovido ao cargo de encarregado da Secção de Engomadeiras, sempre trabalhando na Fábrica Coronel Othon. Hoje ocupa as funções de auxiliar imediato do técnico geral da secção de tecelagem da Fábrica Coronel Othon sendo de justiça salientar o seu esforço e capacidade de trabalho. (...)

JOSÉ TRAJANO DE LUCENA: - Admitido em 18 de novembro de 1928 com quatorze anos, como aprendiz da secção de Bobinas sendo sucessivamente promovido a ajudante de contra-mestre, contra-mestre e atualmente desempenhando as funções de Mestre das Secções de Bobinas, Engomadeiras e Liçador. É um dos mais dedicados dos nossos empregados da Fábrica Coronel Othon.

JOÃO ANASTÁCIO DE LIMA: - Admitido em 28 de novembro de 1928 como aprendiz de tecelagem da Fábrica Coronel Othon, tendo posteriormente passado para apontador, cargo que ainda hoje ocupa com honestidade e zêlo. $(. . .)^{27}$

JOSÉ MARQUES DE BARROS - Foi admitido em 2 de fevereiro de 1928 como servente da seção de Fiação da Fábrica Cel. Othon, não se limitando aos simples misteres da sua função, procurou galgar uma posição de algum destaque, e assim, dentro de certo tempo já se encontrava classificado como "Banqueiro". Dedicandose com maior cuidado ao funcionamento da máquina em que trabalhava, foi por isso promovido a ajudante de contra-mestre e posteriormente, quando adquiriu maiores conhecimentos técnicos, promovido a contra-mestre. $(\ldots)^{28}$

Estes exemplos registrados acima são tipicamente de casos em que a administração fabril podia se orgulhar publicamente de ter empregados com mais de duas décadas de emprego, sobretudo por terem sido empregados fieis, e normalmente ocupantes de cargos estratégicos para a administração fabril. No entanto, não dava conta dos casos de perseguição da estabilidade dos operários sindicalizados no contexto das greves, como também da perseguição encampadas contra a estabilidade dos velhos operários no contexto da institucionalização do FGTS durante a Ditadura de 1964. Como no caso emblemático da operária estável militante, de nome Margarida Oliveira da Silva, em um processo trabalhista no qual denunciou as perseguições políticas que vinha sofrendo por não aceitar a realização de "acordo" com a empresa para abdicação de sua estabilidade decenal, na época da aprovação da lei do FGTS $^{29}$. Ademais, também não dá conta das injustiças cometidas, pela gerência do externo, contra os operários pleiteantes de uma casa para morar dentro da vila operária. Pois na prática, muitos trabalhadores tinham negados seus pedidos de alocação em uma casa, de modo a passarem anos com os nomes na lista de espera gerenciada por Zé Ferreira, sem nunca serem contemplados pelo direito de obtenção de uma moradia na vila 
operária, mesmo que, pela lógica da prioridade elencada na lista, chegasse sua vez de usufruir de tal direito tacitamente assegurado.

Porque os critérios de alocação de operários extremamente especializados e de confiança da administração, e ainda, de operários bem conceituados devido as relações interpessoais mantidas com as pessoas ocupantes de postos na hierarquia, sobressaiam-se demasiadamente por sobre o critério de espera de uma vaga em uma das casas da vila operária com base na antiguidade no emprego, haja vista a escassez dessas casas mesmo após a conclusão das casas do Burity no final da década de 1940. Embora o critério da amizade, parentesco e vizinhança utilizado pela gerência do externo - esta espécie de prefeitura da vila operária da fábrica, materializada na figura do gerente do externo Zé Ferreira, que detinha o controle da ocupação das casas, e que muitas vezes ultrapassava a ordem da lista de prioridades de operários registrados à espera de uma casa da vila operária -, para a administração fabril era prioritário alocar trabalhadores contratados pelos critérios técnicos de admissão. Isto porque a casa constituía-se como um diferencial na disputa pela mão de obra no concorrido mercado de trabalho têxtil, pois funcionava como atrativo diferencial e dava acesso à participação ativa na "economia moral" da vila operária, ou seja, das vantagens materiais oferecidas dentro daquele perímetro.

Com efeito, sobretudo, no que tange aos anos iniciais (última metade da década de 1920), quando a vila operária estava sendo construída gradativamente, até o ano de 1934, a ocupação das casas deve ter sido efetuada, provavelmente, pelos critérios da antiguidade no emprego, com vistas a satisfazer e apaziguar os ânimos dos antigos operários, e por outro lado, pelo critério de atração da mão de obra especializada oriunda das indústrias diversas (operários de caldeiras, mecânicos ${ }^{30}$ ) e das indústrias têxteis propriamente ditas, acirrando a forte concorrência por este mercado de trabalho especializado. Internamente, estes critérios seletivos e restritivos de alocação de trabalhadores nas casas da vila operária demonstram a insuficiência do número de casas da vila operária da Fábrica para atender a demanda total por elas.

Tal escassez no quantitativo de casas para atender a crescente admissão de trabalhadores durante os anos iniciais da administração do "Grupo Othon" arrefeceu apenas entre 1934 e 1939, justamente no lapso de tempo que compreende a entrega das 200 casas em atacado construídas na Carrapateira, as quais se juntaram as já construídas nas imediações da planta fabril, mais precisamente as da Rua do Sol, $1^{\text {o }}$ de Maio, Largo da Fábrica até os anos iniciais da II Guerra Mundial, quando os efeitos da mesma, em termos de mobilização 
industrial, contratação deliberada de mão de obra e "avidez pelo trabalho" ainda não havia sido desencadeado. Com outras palavras, as casas construídas no Burity, embora anunciadas no bojo do programa governamental de Agamenon Magalhães, a Liga Social Contra o Mocambo, na prática apenas veio a repor precariamente a escassez avassaladora de casas para os operários no contexto da exuberante contratação de força de trabalho das fábricas de tecidos, na década de 1940, a fim de dar conta da demanda pela produção nacional desencadeada pelos países europeus beligerantes ${ }^{31}$.

De qualquer modo - a despeito da enorme dificuldade para tal - o fato do operário ser casado e possuir família numerosa, ou ainda em vias de se casar, demonstrando pleno potencial de oferecer mão de obra abundante e naturalmente reproduzida no interior da vila operária - na figura dos filhos menores dos casais, prestes a atingirem a idade mínima para exercer o trabalho de aprendiz nas diversas seções até formarem-se profissional com o aprendizado da prática cotidiana do trabalho (afora os casos dos menores de 14 anos que tinham seus documentos burlados pela administração fabril para iniciarem a vida profissional ainda crianças mesmo) -, era outro critério bastante considerado para se obter o direito à obtenção de uma casa junto à gerência do externo. A história do motorista abaixo demonstra a dificuldade de um trabalhador solteiro conseguir uma casa para morar na vila operária, pelo fato de ser solteiro, por si só, acrescido do fato de não possuir filhos em idade para serem absorvidos como mão de obra, e muito menos com potencial de ter filhos a serem futuramente absorvidos. Como também pelo fato de não ocupar uma posição estrategicamente especializada na produção, sendo deste modo preterido por operários oriundos de outras indústrias, os quais eram atraídos pelo COBM para serem empregados a partir da promessa da garantia de uma moradia na vila operária.

(...) [era a maior dificuldade] pra arranjar [uma casa] aí, porque ia me casar e queria uma casa e aquele Zé Ferreira, que era o chefe, o gerente do Externo, com chapéu, só tinha uma visão ele. Ele não queria arranjar uma casa porque eu era solteiro.

- "você é solteiro, tem um castelo aí na Rua Maria Amália, já mora cinco, seis homens lá e você vai morar...". Eu digo: - "eu vou morar? Se fosse cinco ou seis mulheres eu ia, mas com homem eu não vou com nenhum, tá conversando! (Risos). Eu vou morar com cinco, seis homens nada, eu quero uma casa pra eu me casar e morar nela!".

Aí ele disse:

- "Ali não pode". E ficava me enrolando. Chegava lá no Escritório Central, eu disse:

- "Seu Zé Ferreira cadê a casa?".

- "Não! Ainda não tem, não tem!". Aí chegou um motorista lá e disse: "Não tem? Olha tem duas casas na Rua Estér, tem três na Rua Maria Amália, tem umas três na Rua do Sol". Eu digo: "mas que véio safado, e disse que não tinha, que não tinha casa lá". Aí eu falei com meu chefe, meu chefe era Diretor Financeiro daí do... gostava muito de mim. Aí eu falei com ele: 
- “Olhe, ele não quer arranjar a casa. Zé Ferreira disse que só há casa é pra gente que já tem filho, pra trabalhar na fábrica, a Companhia dá preferência pra um morador pra que venha com filho pra ficar perto da Fábrica. Eu não tenho filho nenhum e ele não quer arranjar a casa". Aí o Seu Zé do Bolo vinha aqui pra Fábrica aí disse assim: (...)

- "Olhe, amanhã você vai lá na Fábrica, fale com Barreto e veja esse negócio da casa, diga que fui eu que mandei”. Aí eu fui no outro dia, cheguei lá e falei com Seu Barreto. Seu Barreto disse:

- "É... Sim, tome aqui a chave aí".

O Zé Ferreira não tava lá no birô dele não. O gerente do externo que não queria arranjar a casa. Mandou[-me] na Rua Ester lá, mandou na Rua Anita. Lá na Rua Estér eu fui, a casa tava destenhorada. "Tá c'uma moléstia, essa casa num morava ninguém aqui não, desse jeito, tem uma cachorra com um cachorro novo", dei um chute na porta assim, que deu cria lá, ficou logo ranhenta, querendo me morder, "vixe nossa senhora, não quero!". Fui em outra, fui em outra... Quando eu cheguei aqui na Fábrica, falei com Seu Barreto.

- "Seu Barreto, não me agradei de nenhuma casa. Tá muito destenhorada. Não me agradei de nenhuma, não!". Aí ele disse:

- "Aí na Rua do Sol tem duas casas desocupadas, vá lá". Aliás, o Zé Ferreira que não queria me dar disse assim:

- "É Seu Barreto, ele vai a essas duas casas aí e veio o gerente, um contramestre de Paulista e veio outro de Camaragibe, veio já olhar essa casa". Aí ele pegou a chave aí disse pra o Zé Ferreira:

- "Zé Ferreira, esse contramestre de Camaragibe e esse contramestre de Paulista, ainda vai chegar, e ele já tá aqui”.

Eu digo:

- "Me dê a chave! Me dê a chave Seu Barreto, me dê!". Aí Seu Ferreira, o velho, ficou fumando como uma onça lá com raiva, que Seu Barreto deu, mas Seu Barreto era maior do que ele, tinha poder mais que ele. Aí veio aí, eu olhei essa aí, que morava Dona... essa mulher que morreu, a mãe dessa galega, como era o nome dela? Didi, Didi?! É, Dona Didi! É, tinha essa desocupada aí, só! Aí eu me agradei dessa. Quando chegou lá eu disse:

- "Pronto Seu Barreto, eu quero essa casa aqui, eu me agradei dessa aqui”. Aí ele disse - era mais ou menos no dia 16, 20 do mês - ele disse:

- "Olhe, no fim do mês, agora não, mas para o mês, no fim do mês já sai descontando o aluguel no seu contracheque". Era um aluguel tão besta que nem se... Era uma besteira, não era Leca, que descontava? Aí pronto, eu fiquei com essa casa, fiquei morando lá na casa. (José, ex-motorista, 2012)

O que nos chama a atenção nesse relato é que embora não preenchesse os principais critérios de alocação de trabalhadores nas casas da vila operária da Fábrica, este motorista ao recorrer ao seu conhecimento pessoal, às boas relações interpessoais travadas com pessoas da hierarquia e conhecedoras das nuances e disponibilidade de casas desocupadas da vila operária, conseguiu à revelia do controle rigoroso do gerente do externo Zé Ferreira, obter o direito a uma moradia localizada na Rua do Sol, a despeito ainda de dois contramestres, um oriundo de Paulista e outro de Camaragibe, certamente com moradia prometida pela administração fabril, de modo a justificar a saída do emprego nestas fábricas em benefício do COBM. Além do mais, este caso demonstra também o quanto a insistência e a utilização correta das pessoas ocupantes de posição estratégica na administração fabril era eficiente para 
ultrapassar, inclusive, critérios mais fortes de alocação, defendidos com bastante ênfase pelo gerente do externo, Zé Ferreira, certamente por ordens superiores. Contudo, o exemplo mostra o quanto mesmo as determinações da alta hierarquia eram relativizadas quando postas em choque com certas situações que envolviam fatores pessoais vinculados a autoridades tal qual a de Seu Barreto que ocupava o posto de Diretor Financeiro na Fábrica. Mas, por outro lado, a intransigência de José Ferreira em assegurar a moradia aos contramestres que estavam para serem contratados junto à Fábrica de Camaragibe e de Paulista, demonstra o quanto este critério utilizado para atrair uma parcela estratégica da força de trabalho para fins da produção e da hierarquia fabril, era bastante utilizado e valorizado pela administração da Fábrica, haja vista a paradoxal atuação de Zé Ferreira neste caso em específico, uma vez que ele encarnava justamente e em grande medida o poder de barganha das relações interpessoais, demonstrado no controle e no favorecimento subjetivo dos operários ao direito à moradia em uma das casas da vila operária.

\section{Conclusão}

Entender a atuação de Othon Bezerra de Mello enquanto industrial e homem público significa também entender a política interna de estabelecimento e exploração econômica da força de trabalho da Fábrica da Macaxeira e do Cotonifício Othon Bezerra de Mello através da política industrial encabeçada por ele. Com capacidade de antevisão econômica, o Coronel Othon alçou-se ao posto de um dos mais prestigiados industriais brasileiros, tornando-se comentador dos assuntos econômicos da rede Diários Associados e integrante da Missão Econômica Brasileira, em 1940, cujo objetivo era o de estabelecer planos para conquista dos mercados externos pela indústria nacional na época da II Guerra Mundial. Em seguida Othon Bezerra de Mello se rebelou contra os grandes industriais do "Sul" do país - aos quais havia se aliado na década de 1930 para, às entrelinhas da lei de restrição de importação de maquinários, promover a modernização de suas fábricas.

Os efeitos de toda essa conjuntura de uma década acirrada de disputa intraburguesa se fizera notar na década seguinte não menos conturbada. $\mathrm{O}$ crescimento desordenado e mal planejado de sua indústria ocasionou internamente a desorganização do próprio sistema de autoridade imposto aos operários pela administração fabril, fazendo emergir uma série de contradições internas e trazendo à público a luta de classes propriamente dita com a atuação contundente do sindicato dos trabalhadores. Entre os anos 1940 e 1960 quatro greves foram 
notáveis para a categoria (1947, 1952, 1958 e 1963), com ampla repercussão pública. Todavia, a figura mítica patronal, sobretudo nos anos iniciais de organização da força de trabalho ao final dos anos 1920 e 1930, foi preponderante para manter esse grupo operário estabelecido, conforme almejava desde 1926 quando constatou a necessidade de se construir a vila operária da fábrica em uma das primeiras reuniões junto aos acionistas. Como vimos, durante essa período a imagem patronal ficou intimamente ligada aos benefícios de se sujeitar ao emprego assalariado fabril, face às garantias de estabilidade, moradia e de direitos trabalhistas. Por outro lado, as desvantagens do emprego formal, a exploração do trabalho realizada dentro da planta fabril era atrelada às hierarquias imediatas, jamais ao patrão.

\section{Notas}

${ }^{1}$ VILAÇA, Antônio. Histórias que Limoeiro Conta. Rio de Janeiro: Arquimedes, 1971.

${ }^{2}$ MORAIS, Fernando. Chatô: O Rei do Brasil, A Vida de Assis Chateaubriand, um dos Brasileiros Mais Poderosos Deste Século. São Paulo: Companhia das Letras, 1994.

3 “ACTA DA ASSEMBLEIA GERAL [EXTRA]ORDINARIA REALIZADA AOS TREZ DIAS DO MEZ DE ABRIL DE 1926" (DOE, 09/05/1926, p. 884).

${ }^{4}$ FOUCAULT, Michel. Vigiar e Punir: nascimento da prisão. Petrópolis: Editora Vozes, 2009.

5 "Directoria da Fazenda Municipal do Recife, em 6 de Maio de 1936, Edital n. 45 (Diario do Estado, 07/05/1936, p. 23-24). As Ruas da Concórdia e do Sol coincidem com a denominação de ruas do centro da cidade. A rua $1^{\circ}$ de Maio, também, apesar que remete ao dia do trabalhador. Enquanto que as demais tomam como nome, referências da espacialização local (a proximidade ao reservatório de água da Fábrica, a fronteira junto ao terreno elevado, referência à fruteiras, árvores, etc). Estas ruas não foram nomeadas com nomes de familiares do patrão, pois eram anteriores à construção da vila operária propriamente dita. E mesmo os nomes atribuídos aos dois principais núcleos habitacionais da vila operária, Carrapateira e Burity, que abrigaram de fato ruas que receberam nomes de parentes do patrão, foram designados a partir da existência de antigas espécies de plantas encontradas no local, certamente por denominação popular do lugar, a exemplo do nome Macaxeira.

${ }^{6}$ OLIVEIRA, Fábio Lucas Pimentel de. Estrutura e Evolução de Capital em Pernambuco: do isolamento relativo ao limiar da integração produtiva. Campinas: UNICAMP (Dissertação de Mestrado), 2011. Revista de Pernambuco, Agosto de 1925, n. 14, pg. 78. O Jornal, RJ, Edição Especial de Pernambuco, “A evolução da indústria de tecidos de algodão em Pernambuco", por OLBM, em 17/set/1928. CETEX. Indústria Têxtil Algodoeira. Rio de Janeiro: MTIC, 1946, p. 312. Prontuários do DOPS n ${ }^{\text {os }} 7.863$ - 8.219 - 27.922.

${ }^{7}$ Sobre a relativização da liberdade do trabalhador ver MARX Karl, O Capital. Livro1: O Processo de Produção Capitalista, Volume 1. São Paulo: Civilização Brasileira, 1968, p. 189. Sobre a "economia moral", ver THOMPSON, Edward P. Costumes em Comum. São Paulo: Cia. das Letras, 1998.

${ }^{8}$ Relatório da Diretoria - 1927. Diário Oficial do Estado de Pernambuco, 28/03/1928, p. 563.

${ }^{9}$ Girardet (1987) em seu Mitos e Mitologias Políticas formula dois modelos antagônicos e complementares de personagens políticos mitológicos, um dos quais chamava de "Salvador" que "em torno deles cristalizavam-se poderosos impulsos da emoção, da espera, da esperança e de adesão", pois em torno destes personagens mitológicos normalmente se formavam constelações de imagens que a nutriam de uma espécie de distinção, tal qual o do patrão ora aqui analisado, devidamente reproduzido enquanto tal por meio do discurso operário que lhes fora inculcado na origem da troca acionária e da formação da vila operária e posteriormente através das gerações, de acordo Girardet. No qual o grande problema estava sempre ligado à dificuldade de demarcação da linha divisória entre a "fabulação legendária" e o "relato de ordem histórica", por conta do "processo de heroificação" desse "mito" seja ele político ou industrial, como é o presente caso.

${ }^{10}$ Para Thompson o termo "paternalista" em partes suaviza a discrição de um sistema de exploração, como que legitimando um ponto de vista a partir de cima, de dentro das casas-grandes das "gentrys" (no caso inglês) ou 
dos senhores de engenho (no caso brasileiro), ao ignorar o outro centro de gravidade do mundo oriundo do cotidiano das gentes pobres marginalizadas. Pois o termo "paternalismo" - "1. Regime baseado na autoridade paterna. 2. Sistema de relações entre o chefe e os seus subordinados segundo uma concepção patriarcal ou paternal da autoridade. 3. P ext. Em política, tendência a dissimular o excesso de autoridade sob a forma de proteção". (Novo Dicionário Aurélio, p. 1281) - como que marca uma visão de condescendência das gentry (dos senhores de engenho e dos industriais que encarnaram tal forma de dominação) para com os pobres - como se aqueles sustentassem estes últimos, e não o contrário. Assim como, marca uma visão retrospectiva, quase mítica, de uma "idade de ouro" antiga que se contrapõe a degenerescência da atualidade moral. Entretanto, na ausência de termos capazes de nomear estes tipos de relações ou na contraposição à possibilidade de usar outro ainda mais generalizante quanto nocivo do "patriarcalismo", Thompson acabou por aceitar, sem se esquivar das ressalvas, a nomenclatura "paternalista" para tratar das relações da classe dominante com a classe pobre camponesa da Inglaterra no século XVII, no artigo "Patrícios e Plebeus" da coleção Costumes em Comum (Cf. Thompson, op. cit, 1998). A historiadora Michelle Perrot acompanhando o arcabouço teórico de E. P. Thompson acrescentou à conceituação adotada por ele, a da família que permeava tipos de dominação industrial caracterizada por três traços peculiares ao sistema de dominação industrial denominado moderno face ao desenvolvimento tecnológico e majoritariamente urbano (ou formador do urbano): 1) "a presença física do patrão nos locais de produção", onde a casa do senhor ocupava posição central no espaço territorial de abrangência da fábrica; 2) "as relações sociais do trabalho concebidas conforme o modelo familiar", no qual o "pai" é o próprio patrão, enquanto os operários seus "filhos", num sistema de disposições de relações entre classes sustentador de uma concepção de que o emprego é garantido e assegurado pelos patrões aos seus dominados juntamente às "instituições de previdência" subsidiárias à relação empregatícia e garantidoras das condições materiais de existência dos subordinados; e finalmente 3) que "os trabalhadores aceitavam essa forma de integração", e até a reivindicavam, porque o paternalismo só poderia ser concebido com a adesão operária, sendo uma relação recíproca de imposição do patrão e aceitação do operário, que sem a participação dos dois lados deixaria a mesma de existir (Perrot, 1988).

11 Depoimento da ex-tecelã Tôta ao grupo da Federação das Associações de Bairro de Casa Amarela. VENTURA, Iêda et al. Casa Amarela: Memórias, Lutas e Sonhos. Série I - Entrevistados. Recife: Departamento de Memória de Casa Amarela, FEACA, 1988, p. 46.

12 "Os nossos comicios". Norte Proletario, 22/01/1932, p. 1.

${ }^{13}$ STEIN, Stanley. Origens e Evolução da Indústria Têxtil no Brasil - 1850/1950. Rio de Janeiro: Ed. Campus, 1979; MORAES, Emanuel. A Fábrica de tecidos da Macaxeira e a vila dos operários: a luta de classes em torno do trabalho e da casa em uma fábrica urbana com vila operária (1930-1960). Dissertação de Mestrado, UFPE, 2017.

${ }^{14}$ LEITE LOPES, José Sérgio. A Tecelagem dos Conflitos de Classe na Cidade das Chaminés. São Paulo: Marco Zero Editora, 1988.

${ }^{15}$ BEZERRA, Daniel Uchoa Cavalcanti. Alagados, Mocambos e Mocambeiros. Recife: Imprensa Universitária, 1965; PANDOLFI, Dulce Chaves. Pernambuco de Agamenon Magalhães: Consolidação e Crise de uma Elite Política. Recife: Fundação Joaquim Nabuco/Editora Massangana, 1984.

${ }^{16}$ Anuário estatístico do Brasil 1936. Rio de Janeiro: IBGE, v. 2, 1936.

${ }^{17}$ De acordo com depoimento da ex-tecelã da Fábrica Bezerra de Mello e militante do Partido Comunista, Júlia Santiago, houve na ocasião, na Fábrica Bezerra de Mello, na Praça Siqueira Campos, uma pequena mobilização grevista de operários para que o patronato cumprisse o determinado pela lei que instituiu a carteira profissional de trabalho:

"O pagamento era certo, era feito, seis cruzeiros, seis tostões, não era tempo do cruzeiro. Houve um decreto quando Getúlio - ele era ditador - depois houve eleições, ele foi eleito e passou a dar o salário, isso já em trinta e três, porque a gente trabalhava sem carteira assinada. Passou a existir nessa época a carteira profissional. Desde aí tenho carteira. Eles não queriam dar. Foi nessa ocasião, a primeira vez que participei de uma greve. A gente começou com apenas dez pessoas, porque o pessoal tinha medo. Eu sempre me reunia com o pessoal da fábrica... Vieram duas meninas e dois rapazes, do Rio de Janeiro, para nos ajudar. 'Foi um decreto de Getúlio e vamos fazer com que seja cumprido'. Então, a gente jogou o patrão em cima do governo. 'Bom agora vamos defender um direito que o Presidente deu pra gente... '. Eles então disseram que iam botar a gente para fora. Eu já tinha seis anos de fábrica, não tinha medo de ninguém, eu sabia de tudo... E, começamos a lutar...".

(Júlia Santiago da Conceição - Acervo de História Oral da FUNDAJ - MPM-70).

${ }^{18}$ Para se ter uma ideia do que representava a mudança na concepção do tempo e da disciplina do trabalho na sociedade capitalista industrial ver o artigo "Tempo, disciplina de trabalho e capitalismo industrial" em Thompson, op. cit., 1998, pp. 267-304.

${ }^{19}$ Sobre este direito e sua extinção na década de 1960 ver MORAES, Emanuel. "O processo de extinção da estabilidade do trabalhador celetista e a instituição do FGTS: o caso dos operários da Macaxeira (1964-1969)”. 
IN: Anais do VII Seminário TRT/UFPE [e] II Caravana ANPUH/PE: história, direitos e trabalho / organização Márcio Vilela, Pablo Porfírio, Arthur do Nascimento. Recife: Ed. UFPE, 2018.

${ }^{20}$ Bourdieu em "A Greve e a Acção Política" (2003, pp. 263-275), com base no pensamento do economista O. W. Phelps diz que existem "mercados de trabalho", no plural mesmo. Esse conceito de "mercados de trabalho" dá conta de que não há um mercado de trabalho único e homogêneo, mas "mercados de trabalho", os quais têm funcionamentos próprios e são explorados de formas específicas pelos empregadores que recorrem a cada um desses de acordo com as suas necessidades e conveniências.

${ }^{21}$ Cf. a perspectiva de análise "patrimonislista" weberiana de Juarez Rubens Brandão Lopes, em seu clássico estudo da sociologia industrial Crise do Brasil Arcaico (1967, pp. 11-18); e, por outro lado, a crítica de José Sergio Leite Lopes a essa perspectiva generalizante de Brandão Lopes perceber a forma específica de dominação exercida pela grande indústria por sobre o proletariado industrial em uma pequena cidade. De acordo com Leite Lopes, no artigo "Sobre os trabalhadores da Grande Indústria na pequena Cidade: Crítica e Resgate de Crise do Brasil Arcaico", IN: Cultura e Identidade Operária (1987, pp. 147-170), esta análise generalizante, baseada no conceito de "patrimonialismo" de Max Weber e sustentada por Brandão Lopes, incorre justamente no erro de levar em consideração a análise na perspectiva do capital, ao invés de adotar o ponto de vista da força de trabalho como ponto de partida da análise dessa forma de dominação.

${ }^{22}$ Cf. o conceito de "obreirização" (Bourdieu, 2003, idem). Tal conceito, segundo o próprio Bourdieu era derivado do conceito de asilization de Goffman, o qual se referia ao processo de adaptação/apropriação do sujeito nos asilos (ou nas "instituições totais" de um modo geral) e de serem adaptados/apropriados, ao mesmo tempo, pelo espaço institucional, ao longo de suas estadias nestas "instituições totais". No caso de Bourdieu, o uso é bastante similar, apenas que se refere para o caso específico do processo de "obreirização" dos trabalhadores rurais e urbanos não-qualificados em operários das fábricas modernas, de modo que o conceito foi exemplarmente utilizado por José Sérgio Leite Lopes em Mudança Social no Nordeste e em A Tecelagem dos Conflitos de Classe na Cidade das Chaminés.

${ }^{23}$ Engels (1979) mostra o quanto no valor intrínseco do salário já se computava o valor da moradia e o quanto à medida que a moradia tornava-se uma realidade concreta para o trabalhador, tal valor era deliberadamente deduzido do salário. A única diferença é que nestes escritos Engels refere-se à questão da propriedade de uma moradia pelo proletariado alemão. E no nosso presente caso, trata-se do pagamento módico de valor de aluguel de um operário inquilino de seu patrão.

${ }^{24}$ O Relatório (de 1926) aos acionistas assim se referiu à antiga administração: “(...) a nova Companhia Fabrica de Tecidos de Apipucos tem grande satisfação em deixar consignados neste documento os relevantes serviços prestados á antiga empresa pelo honrado dr. Antonio Braz da Cunha, seu fundador e que durante mais de 30 annos a dirigiu com reconhecida competência e escrupulosa probidade" (grifo nosso).

${ }^{25}$ Entrevistamos operários que afirmaram serem originários também de Nova Descoberta, Alto Santa Izabel, Alto do Mandú, inclusive, uma de Casa Forte (localidade relativamente mais distante, embora pertencente a mesma Região Político-Administrativa (RPA-3 atual) e da antiga Freguesia do Poço).

${ }^{26}$ Pairava certa "fama" moralmente negativa das seções de fiação, sobretudo, e de tecelagem, para as mulheres. Não à toa muitos pais rejeitavam o acesso ao emprego na Fábrica de suas filhas, bem como muitos maridos retiravam suas mulheres do ambiente fabril após o casamento.

27 "Decorreu com invulgar entusiasmo a "FESTA DA EFICIENCIA" promovida pelo Cotonifício Othon Bezerra de Mello S. A.". DP, 27/01/1954, p. 8, 9 e 10.

28 “A FESTA DA EFICIENCIA - A MAIS EXPRESSIVA E MARCANTE HOMENAGEM DA INDÚSTRIA PERNAMBUCANA AOS SEUS OPERARIOS”. DP, 05/02/1955, p. 8, 9, 10 e 11.

29 “(...) Disse a Recda. que aplicou à Recte. as suspensões contra as quais reclama, em virtude de haver ela se recusado, repetidamente, a prestar serviços nas condições vigorantes para tôda a sua secção de trabalho. Provou, porém, a Recte., com as testemunhas que apresentou, que a Recda., após a haver transferido da Fábrica Amalita, localizada na Praça Sérgio Loreto, para a Fábrica Cel. Othon, que fica na Macacheira, (no extremo oposto da cidade, cêrca de 10 ou mais quilômetros do seu primeiro local de trabalho), porque a mesma se recusara a trabalhar com maior número de teáres, pretendia obrigá-la a trabalhar com 4 teáres antigos, tipo conhecido por "pé duro", submetendo-a a um esfôrço superior as suas forças. (...). Proc. n 1.327/65-TRT, 5 JCJ, TRT.

${ }^{30}$ Leite Lopes, op. cit., 1979, pp. 187-188, sobre a mobilidade pelos mercados de trabalho das usinas e das fábricas têxteis dos chamados operários "artistas" em detrimento da relativa imobilidade dos "profissionistas".

${ }^{31}$ Neste contexto, a gerência da fábrica chegou a adotar a medida extrema de impor a divisão dos cômodos das casas para mais de uma "chapa", ou seja, para mais de uma família operária, o que significava duas ou mais famílias morando sob o mesmo teto devido a superpopulação da vila operária durante a vigência do contexto econômico desencadeado com a II Guerra Mundial. 


\section{Referências Bibliográficas}

BEZERRA, Daniel Uchoa Cavalcanti. Alagados, Mocambos e Mocambeiros. Recife: Imprensa Universitária, 1965.

BOURDIEU, Pierre. "A Greve e a Acção Política”. IN: Questões de Sociologia. Lisboa: Fim de Século, 2003, pp. 263-275.

CETEX (Comissão Executiva Têxtil). Indústria Têxtil Algodoeira. São Paulo: Indústria Gráfica Cruzeiro do Sul, 1946.

COLLIER, Eduardo. Carlos Alberto Menezes: Pioneirismo Sindical e Cristianismo. Recife: Digital Graph Ed., 1996.

ENGELS, Friedrich. A Questão da Habitação. São Paulo: Aldeia Global Editora, 1979.

FOUCAULT, Michel. Vigiar e Punir: nascimento da prisão. Petrópolis: Editora Vozes, 2009.

GIRARDET, Raoul. Mitos e Mitologias Políticas. São Paulo: Companhia das Letras. 1987.

LEITE LOPES, José Sérgio (Org.). Mudança Social no Nordeste: A Reprodução da Subordinação. São Paulo: Paz e Terra, 1979.

LEITE LOPES, José Sérgio (Coord.). Cultura e Identidade Operária: aspectos da cultura da classe trabalhadora. São Paulo: Marco Zero Editora, 1987.

LEITE LOPES, José Sérgio. A Tecelagem dos Conflitos de Classe na Cidade das Chaminés. São Paulo: Marco Zero Editora, 1988.

LOPES, Juarez Rubens Brandão. Crise do Brasil Arcaico. São Paulo: Difusão Européia do Livro, 1967.

MARX, Karl. O Capital. Livro1: O Processo de Produção Capitalista, Volume 1. São Paulo: Civilização Brasileira, 1968.

MELLO, Leticia Bezerra de (Org.). Othon, 100 Anos: Uma História de Ousadia e Sucesso. Rio de Janeiro: Gráfica Bela.com, 2005.

MORAES, Emanuel. A Fábrica de tecidos da Macaxeira e a vila dos operários: a luta de classes em torno do trabalho e da casa em uma fábrica urbana com vila operária (19301960). Dissertação de Mestrado, UFPE, 2017.

MORAES, Emanuel. "O processo de extinção da estabilidade do trabalhador celetista e a instituição do FGTS: o caso dos operários da Macaxeira (1964-1969)". IN: Anais do VII Seminário TRT/UFPE [e] II Caravana ANPUH/PE: história, direitos e trabalho I organização Márcio Vilela, Pablo Porfírio, Arthur do Nascimento. Recife: Ed. UFPE, 2018. 
MORAIS, Fernando. Chatô: O Rei do Brasil, A Vida de Assis Chateaubriand, um dos Brasileiros Mais Poderosos Deste Século. São Paulo: Companhia das Letras, 1994.

OLIVEIRA, Fábio Lucas Pimentel de. Estrutura e Evolução de Capital em Pernambuco: do isolamento relativo ao limiar da integração produtiva. Campinas: UNICAMP (Dissertação de Mestrado), 2011.

PANDOLFI, Dulce Chaves. Pernambuco de Agamenon Magalhães: Consolidação e Crise de uma Elite Política. Recife: Fundação Joaquim Nabuco/Editora Massangana, 1984.

PERROT, Michelle. Os Excluídos da História. Rio de Janeiro: Paz e Terra, 1988.

SCOTT, James C. A Dominação e a Arte da Resistência: discursos ocultos. Lisboa: Livraria Letra Livre, 2013.

STEIN, Stanley. Origens e Evolução da Indústria Têxtil no Brasil - 1850/1950. Rio de Janeiro: Ed. Campus, 1979.

THOMPSON, Edward P. Costumes em Comum. São Paulo: Cia. das Letras, 1998.

VENTURA, Iêda et al. Casa Amarela: Memórias, Lutas e Sonhos. Série I - Entrevistados. Recife: Departamento de Memória de Casa Amarela, FEACA, 1988.

VILAÇA, Marcos Vinicius. Coronel, Coronéis: apogeu e declínio do coronelismo no nordeste. Rio de Janeiro: Bertrand Brasil, 2003 ( $4^{\text {a }}$ Ed.).

\section{Fontes Orais}

CAMPELO, Edite. [85 anos]. [dez.2012]. Entrevistador: Emanuel Moraes. Recife, PE. 29.dez.2012.

QUEIROZ, José. [77 anos]. [dez.2012]. Entrevistador: Emanuel Moraes. Recife, PE. 29.dez.2012.

LIMA, Francisco dos Santos. [79 anos]. [jan.2013]. Entrevistador: Emanuel Moraes. Recife, PE. 21.jan.2013.

NUNES, Maria de Lourdes. [82 anos]. [out.2012]. Entrevistador: Emanuel Moraes. Recife, PE. 29.out.2012.

SILVA, Abdias José da. [77 anos]. [mar.2013]. Entrevistador: Emanuel Moraes. Recife, PE. 03.mar.2013. 